\title{
Who Drives the Automotive Sector? Thailand Selective Policies
}

Chiara Pollio (University of Ferrara and c.MET05) pllchr@unife.it

Lauretta Rubini (University of Ferrara and c.MET05) rbnltt@unife.it

\begin{abstract}
:
Purpose: We critically analyse the case of selective industrial policies for automotive industry in Thailand.

Approach: Founding on previous literature and official government documents, we describe the implemented policies, dividing them in four phases according to the main trend they followed. We suggest which results the policies have or have not reached by analysing the current state of the sector.
\end{abstract}

Findings: Our main point is that selective policies implemented in the country were successful in helping the development of the sector as a whole, contributing to the role of Thailand as main actor in the international market. However, such policy initiatives were not able to solve some of the main issues of automotive sector in the country related to local development, such as the technology dependence on foreign (mainly Japanese) firms and the weakness of local suppliers.

Keywords: Automotive Industry; Thailand; Industrial Policy; Selective Policies.

Article classification: Research Paper 


\section{Introduction}

The automotive industry has always been one of the most important targets in industrialisation plans of developing countries. This is so for several reasons: on the one hand, the establishment of such sector means the involvement of large amounts of investments, together with the creation of employment and consumption (Phongpetra and Johri, 2011). On the other hand, the automotive industry has always been believed to generate several important backward and forward linkages with other areas both of manufacturing and services, thus generating transfer and spillover effects to the whole economy. Finally, and because of the aforementioned motives, rather than being a mere mean of transport, the automobile has historically represented a metaphor of the whole process of capitalistic development of societies. This is clear for countries such as the U.S. in the first half of the twentieth century, Europe after the WWII and Japan since the '80s. It is also the case of China today, with its big SOEs that are linked in joint ventures with the most important transnational manufacturers, a strategy that is allowing Chinese assemblers to climb the international ranking of automakers.

However, it is less known - and less explored in the literature - that the automotive sector has been at the centre of industrial policy efforts of many developing countries in Southeast Asia. Perhaps the most relevant case among these is Thailand, one of the main economies in Southeast Asia ${ }^{1}$. According to the World Bank (1993) the country was to be included among the new Asian tigers for its impressive rates of growth, that the World Bank report attributed mainly to functional policies by national governments - in opposition to the structural initiatives implemented by the NIEs of Northeast Asia (Jomo, 2005). Five years later, the country was the epicentre of a violent speculative attack on its currency, which propagated to the rest of East Asian countries and is nowadays known as the Asian Crisis (1997-98). Since then, Thailand has slowed down its pace towards the chatch-up of developed countries. Unable to break the glass ceiling of middle income levels, the country lingers together with other ASEAN ${ }^{2}$ countries in the so-called "middle income trap" (Ohno, 2009; Di Tommaso and Angelino, 2015; Angelino and Masina, 2014).

In this context, we focus on the automotive sector to analyse one of the most interesting cases of selective policies - that is those initiatives aimed at supporting a specific group of actors, territories or sectors (Lall, 2004; Pianta, 2014; Worwick and Nolan, 2014) in this region. The aim of this paper is to highlight the direction that the policies for the sector in this country took during a fifty-year-long experience, in which cases they were successful and when instead the government could not generate the expected effects on its local production environment. In fact, Thailand is one of the leading producers and exporters of vehicles and auto parts worldwide, but it has no national brand or firm in the lead of this process. The main actors of this sector, indeed, are foreign multinationals, both with respect to the automakers and the parts makers. This confers some strengths as well as some weaknesses to the sector itself. We may indeed suggest that this sector's development may be looked at as a metaphor of the general growth trajectory of this country.

The outline of the paper is as follow. In the next section we offer a brief description of the international context of the sector, where Thailand plays as a main actor both globally and regionally. Section 3 analyses the current state of the automotive industry in the country, whose main feature, at least on the descriptive level, can be ascribed to the interaction between the international context and the national industrial policies. Both these factors of the

\footnotetext{
${ }^{1}$ Thailand is the twentieth country worldwide for its population, and the seventeenth for manufacturing productions. It is also the twentieth country in the world in terms of exports and the twenty-eighth in terms of GDP (data for 2014, source: World Bank).

${ }^{2}$ Association of South-East Asian Nations.
} 
sector's development are addressed in section 4. To conclude, in section 6 we introduce some final remarks about the main principles that in our view inspired these selective policy interventions, which we frame in an interpretative scheme based on the separation between results for the sector and results for local development.

\section{The International Role of Thailand}

In 2015, Thailand was the twelfth vehicle producer worldwide, with $1,915,420$ manufactured units, and exported more than 62 percent of such production ${ }^{3}$. The country's figure are larger than the UK's, and amount to about half of those of some giants of the sector such as South Korea and India.

Additionally, Thailand's vehicle production growth rate is one of the highest worlwide, as it is shown in figure 1 . The growth of the country is impressive not only when compared with the traditional centres of motor vehicle production that are nowadays stagnating - that is EU-15, Japan and the U.S. - but also with respect to the average of Asian countries, whose trend is steadily positive. This confirms the role that the country has in the global sector for the present and, most likely, for the future.

Fig. 1 - Vehicle production growth rate for selected regions and countries. Base year 1997

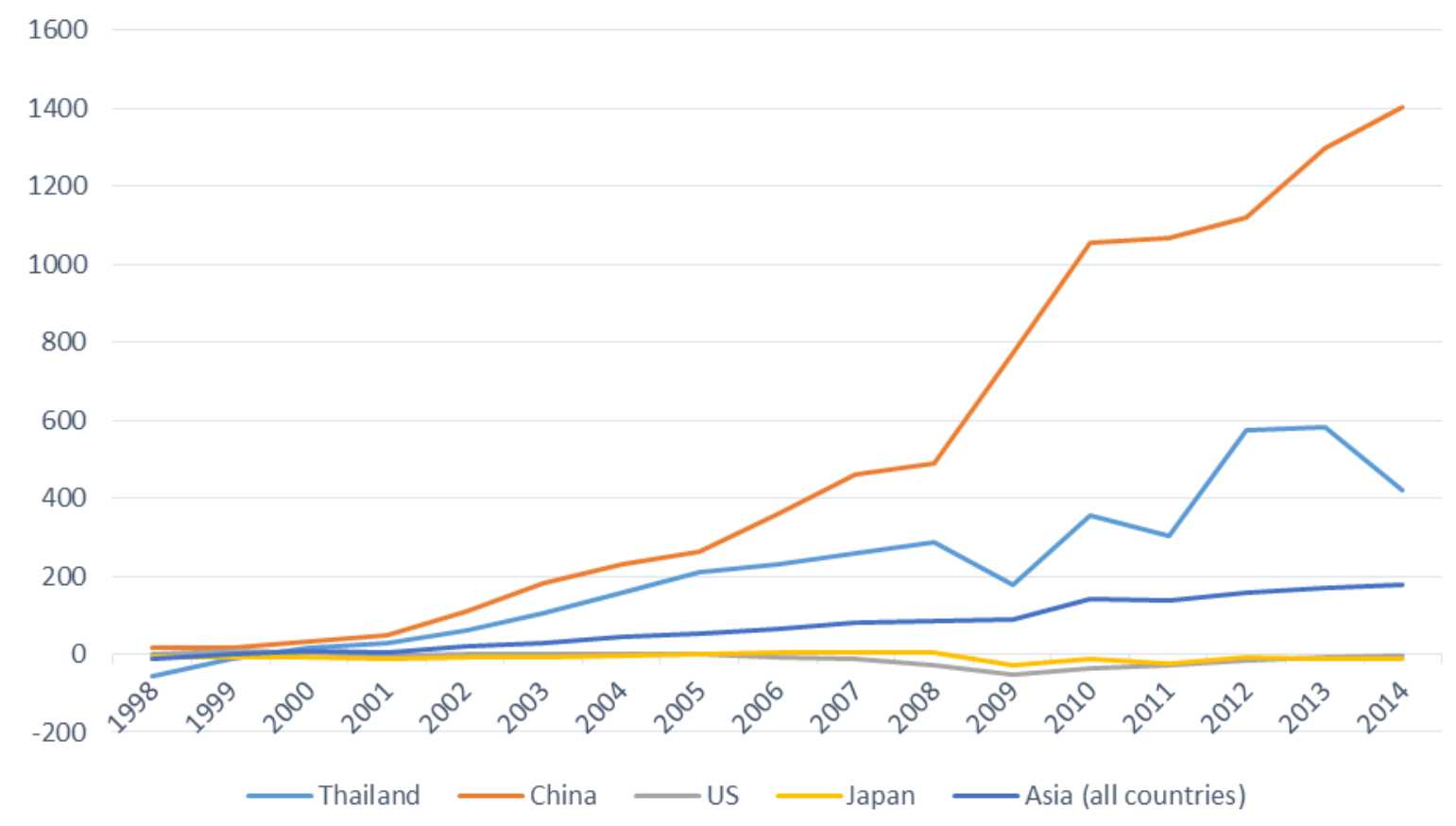

Source: authors' elaboration on data by OICA.net.

Thailand is also one of the champions for some market niches, particularly for what concerns exports. In recent years, in fact, it is the second largest producer of 1-ton pickup trucks worldwide (Kaiser, 2014) after the U.S. This primacy makes Thailand one of the strongest manufacturers for the overall category of light commercial vehicles: since the late '90s, in fact, it ranks among the very first positions, with production volumes over 1 million vehicles, and particularly in 2000s it is steadily among the first five manufacturers worldwide ${ }^{4}$. In the field of light commercial vehicles (under 5 tons), Thailand is an export

\footnotetext{
${ }^{3}$ Sources: OICA.net, TAIA.or.th.

${ }^{4}$ Source: OICA.net
} 
champion too: it is the first global exporter for the category with diesel engines, and the second if those with combustion engines are added (year 2015) ${ }^{5}$.

In the global context, Asia is certainly the world region where the sector has seen the largest growth since the '90s, reaching nowadays production volumes similar to those of Europe and the U.S. Even if one compares Thailand's performance with Asia's, the country's strength is apparent (fig. 2).

Fig. 2 - Production of motor vehicles (motorcycles excluded) in Thailand and in the rest of Asia-Oceania

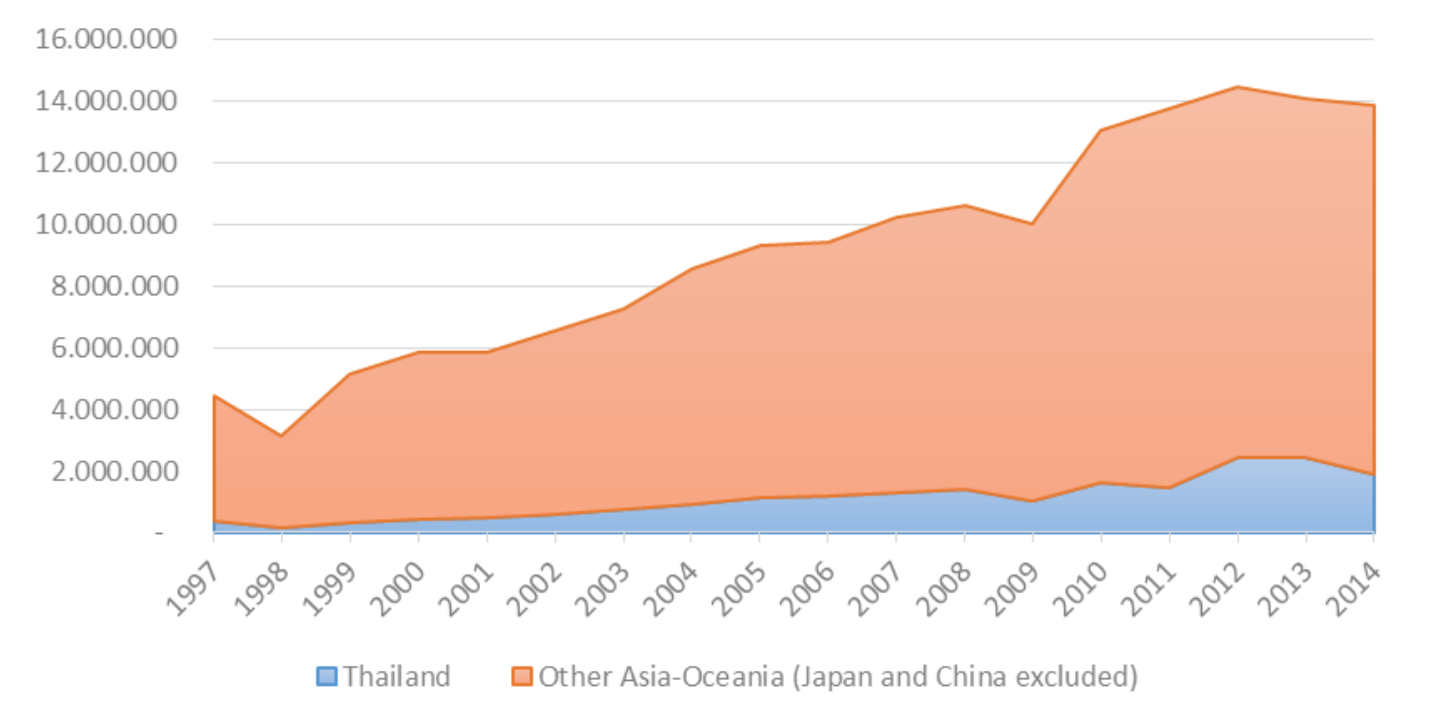

Source: authors' elaborations on OICA.net data (last retrieved - march 2016).

Thailand ranks fifth in the region, behind the global champions of the sector - Japan and South Korea - and the continent's demographic and economic giants - China and India. However, if we exclude Japan and China from the counting ${ }^{6}$, Thailand's contribution to the production of the region has grown from 5-6 percent of the total in post-asian crisis years to over 18 percent in 2015.

\section{The Automotive Sector Today}

Figure 3 shows Thailand's trends of production, domestic sales and exports for the year range 1993-2014. Starting from 1998 the sector has seen a large growth: in 20 years (1995-2014), production has increased fourfold, while exports have passed from few thousands to more than one million; also sales in the domestic market has risen, although at a lower pace. National and international sales seem to follow different path. For the first, the period between 2012 and 2014 was characterised by a drop, due to a phase of political turmoil that led to the twelfth coup d'etat since $1932^{7}$ and to the abolition of consumption incentives for the sector (Kobayashi, Jin and Schroeder, 2015; Kobayashi, 2014b). In the same period, and in general in the last years, data on export are more steadily growing. On the contrary, during the international crisis era, export fell while domestic sales kept a much stable trajectory.

\footnotetext{
${ }^{5}$ Source: UNcomtrade.

${ }^{6}$ The two countries have a particular role in the sector, which would distort the estimation related to the other players in the area: China has an enormous production, which however is mainly oriented to the domestic market, while Japan has a consolidated global leading position.

${ }^{7}$ Source: http://www.economist.com/blogs/banyan/2014/05/thailands-coup.
} 
In addition to the core position that Thailand has in the international automotive market, it is important to note the important role of the sector for the country's economy, although several weaknesses remain.

Fig. 3 - Production, domestic sales and exports for motor vehicles in Thailand, volumes

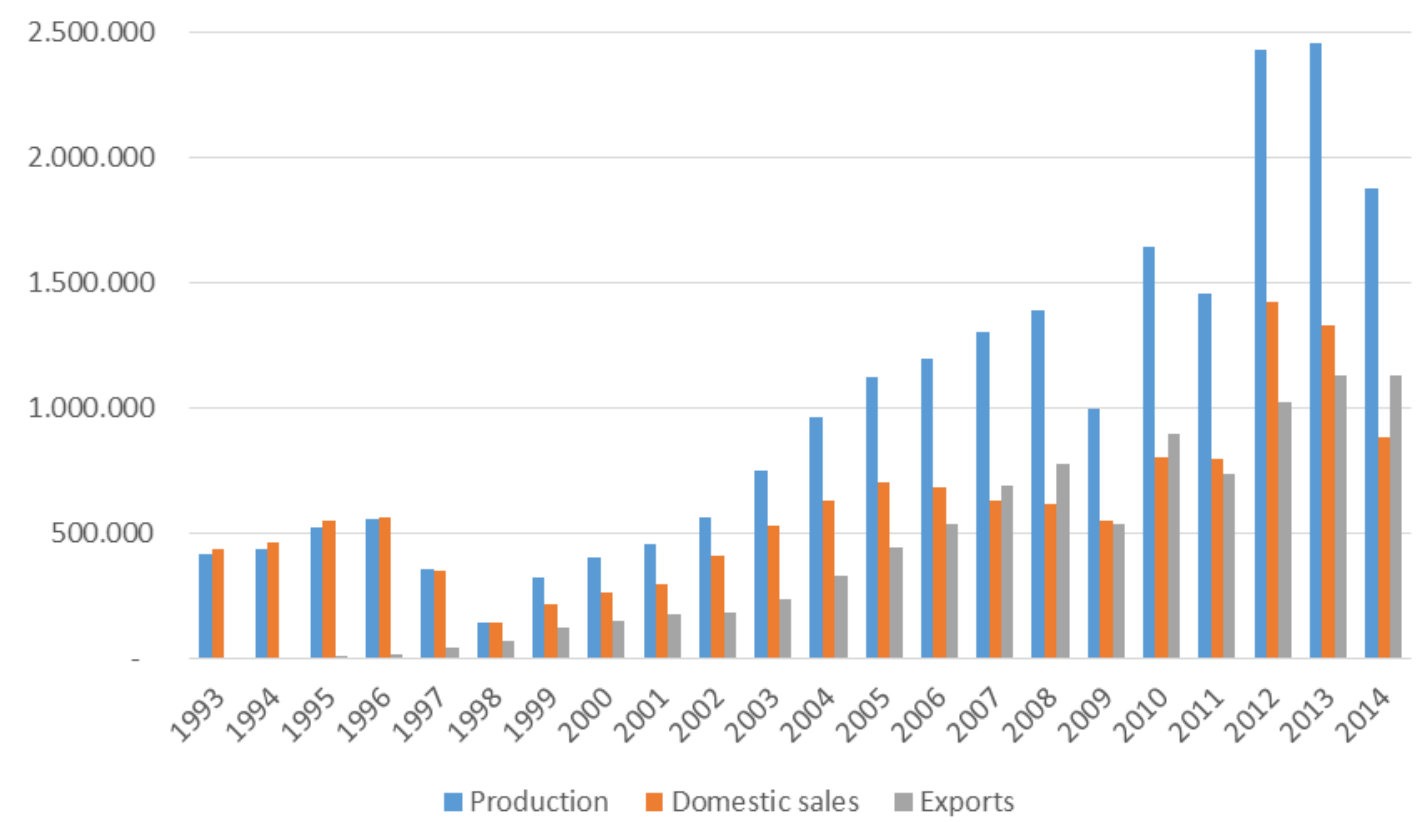

Source: authors' elaboration on data by Thailand Automotive Institute, Federation of Thai Industries, OICA, Bank of Thailand.

The sector represents about 12 percent of national GDP (BoI, 2015) and in 2012 it employed about 525,000 workers (10 percent of the manufacturing). In the same year, it was the second sector for exports, amounting to a value of 15 percent of total manufacturing exports, a third of which consisted in components. Additionally, FDI totalled over 17 billion of US dollars (21 percent on total FDI for manufacturing). Currently, there are about 3.000 plants that are involved in the automotive production chain, more than 96 percent of which are part of the supply (tab. 1).

\section{[TABLE 1 ABOUT HERE]}

In terms of the geographical distribution of the sector, the automakers are almost totally concentrated in two areas: a) Bangkok and the neighbour districts (Samut Prakan and Pathumthani); b) the Easter Seaboard, that is Rayong, Chaochengsao and Chonburi provinces (fig. 4). As we shall see later, both these regions were at the centre either of processes of colocalisation promoted by the government (Bangkok and the surrounding area in the '80s), or of clustering policies (the Eastern Seabord in the 2000s). The part makers mainly followed the assemblers, by localising their operations in the same industrial areas.

Fig. 4 - Localisation of main OEMs and suppliers, 2012

a) OEMs 


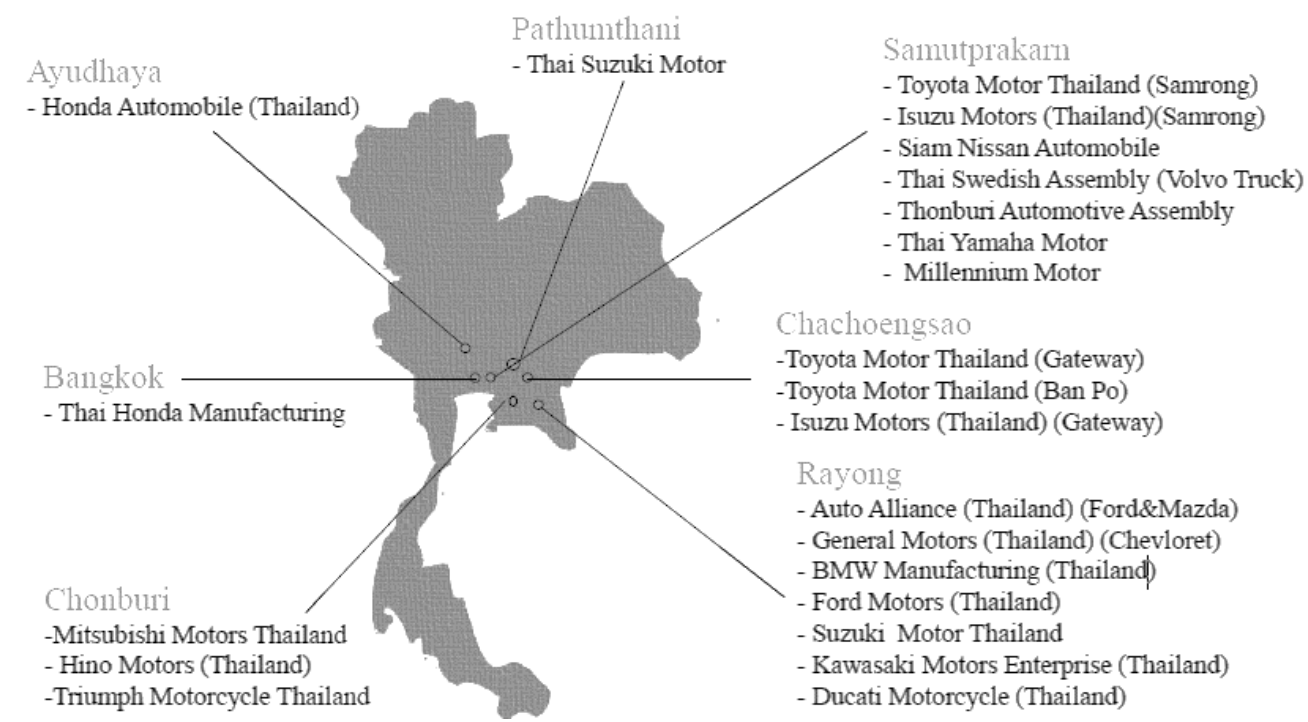

b) Main suppliers

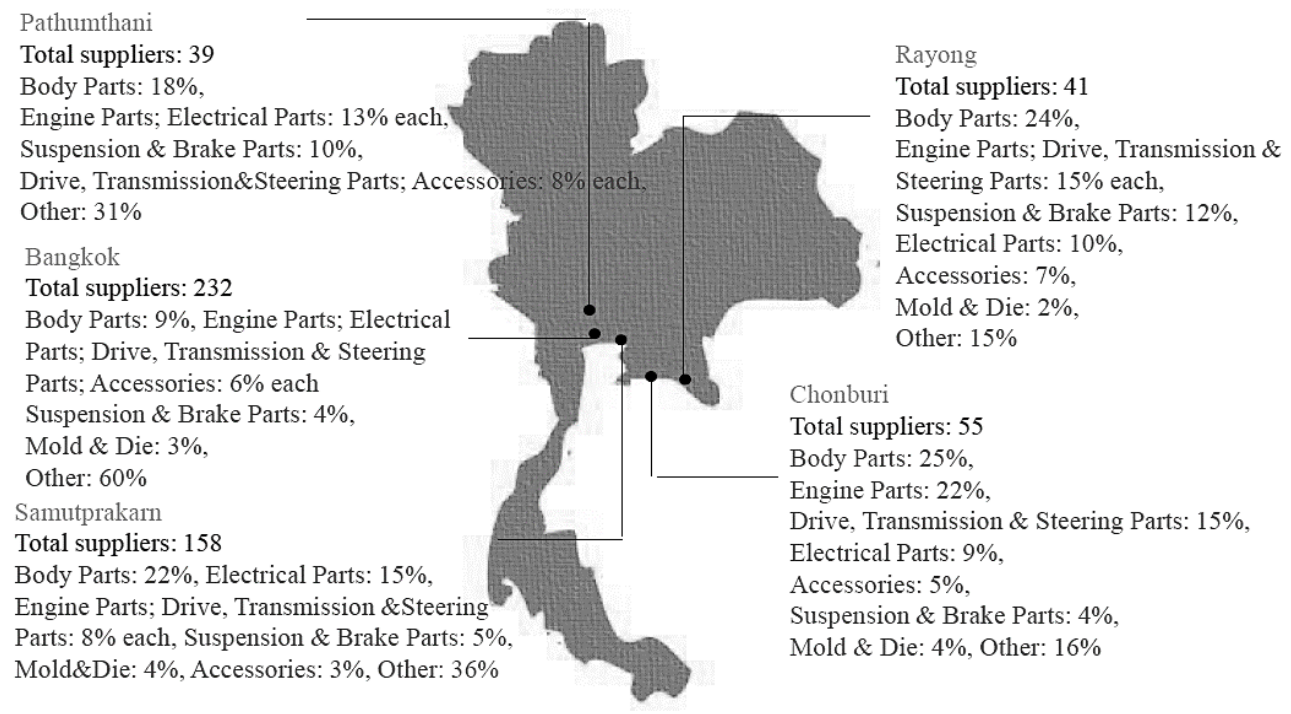

Source: BoI.

\subsection{Supply structure: automakers}

When speaking about the automotive sector in the country one should carefully take into account that Japanese automakers (or Original Equipment Manufacturers - OEMs) and supply chain have a dominant position in the production. In fact, nowadays the whole automotive production is exclusively based on foreign - mainly Japanese - automakers. In fact, among the first nine automakers in terms of sales and production in 2015, only two (Ford and General Motors) are non-Japanese (fig. 5). It will be clearer later how the current supply structure of the sector, and the supremacy of foreign capitals, is the result of the influence of both the exogenous factors, the effects of the Asian Crisis and the policies implemented by the government (see section 4).

The sector seems to be firmly concentrated in few actors' hands: although the Thailand Automotive Industry Association - the national category association for automakers - 
includes 34 members $^{8}$, Toyota, Mitsubishi and Isuzu holds two third of the total production and domestic sales. Additionally, there are no national brands in the market, neither the government ever promoted their birth.

Fig. 5 - Production and sales by brand, 2015

a) Production

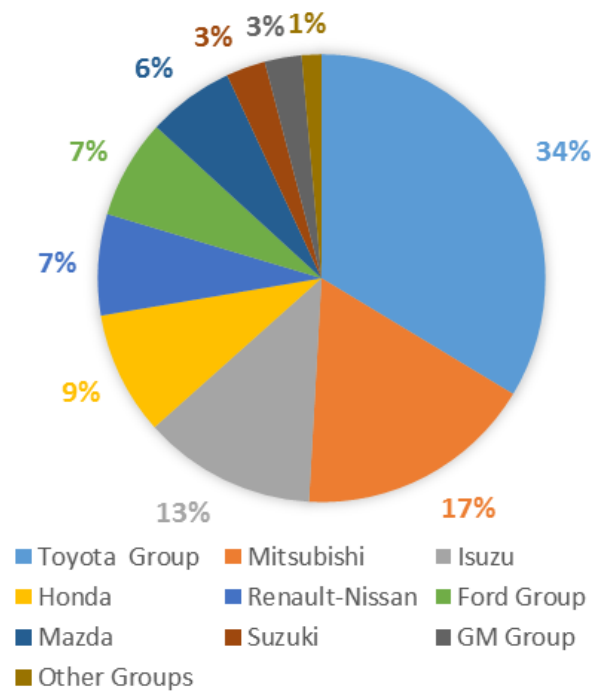

b) Sales

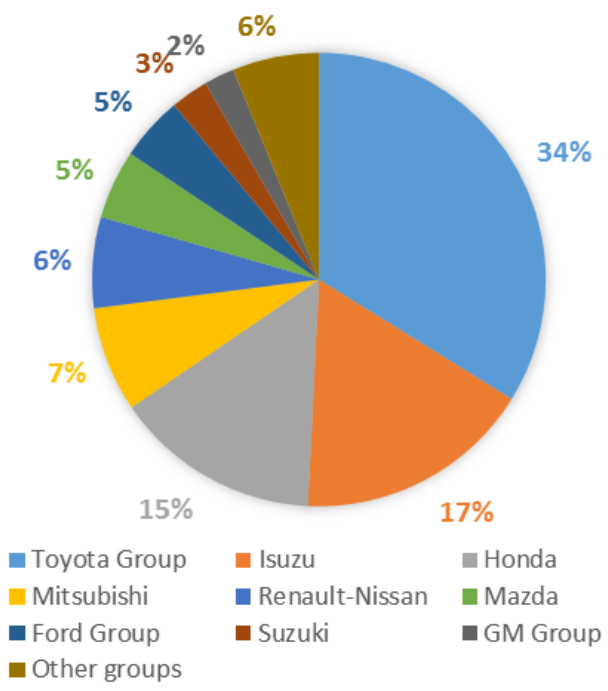

Source: authors' elaboration on data Marklines.com.

The vast majority of automakers that operate in the country is mainly oriented toward export (tab. 2): with the exception of Isuzu, that mainly produces light commercial vehicles for the domesti market, the largest Original Equipment Manufacturers (OEMs) generate from 60 (Toyota, Mazda and Hoda) to 80 percent (Mitsubishi, Ford) of their total revenues from exports.

\section{[TABLE 2 ABOUT HERE]}

\subsection{Supply Structure: supply chain}

In general, the components' production chain in the automotive sector has a stratified and pyramidal structure (see among others Frigant, 2011; Sturgeon, Memedovic, and Van Biesebroeck, 2009; Sturgeon, Memedovic, and Van Biesebroeck, 2008; Humphrey and Memedovic, 2003). At the top of the pyramid there are the large first-tier suppliers. These firms, that in 2015 in Thailand were 709 (BoI, 2015), are in charge of the production of subassembly, modules on large scale and complex parts. They also take responsibility in the design and engineering in collaboration with the OEMs, as well as in the control of quality and production times in the lower levels of the chain.

According to 2011 data, 50 percent of the first-tier manufacturers was totally Thaiowned, 40 percent was mainly foreign-owned and the remaining 10 percent was mainly Thaiowned (tab. 3). However, the role of Thai firms is different from that of foreign ones, as they implement simpler and less technology-intensive productions, as it is reasonable to expect given the history and the current composition of the sector (Johri and Petison, 2008). In fact, the Thai-owned firms are mainly focused on the body and on other parts, while foreign production is larger for what concerns core activities, such as engines, electrical and transmission systems: these are the types of productions that require larger design and technological capabilities (Intarakumnerd and Charoenporn, 2015).

\footnotetext{
${ }^{8}$ Source: TAIA.com.
} 


\section{[TABLE 3 ABOUT HERE]}

Among the first-tier firms, a core role is played by the so-called global suppliers: these firms are the most important actors in the global production chain, and their revenues are estimated to amount to about 88 percent of the total value of sales in parts and components worldwide $^{9}$. Thailand hosts a large number of global suppliers: according to 2014 data, 64 among the first 100 have established operations in the country. The majority of them are Japanese (26), while the others mainly come from the U.S. (15) and Germany $(11)^{10}$. In the case of global suppliers, the marginality of Thai producers is even more evident: not only there are no Thai suppliers among the first 100, but even if one enlarges the observation to the first 500 suppliers in the world, only one of them is Thai-based and Thai-held ${ }^{11}$. As it will be clear in the following section, both the large presence of foreign and particular Japanese suppliers and the absence of large global Thai suppliers can be seen as the - both voluntary and unintended - results of the policies oriented to the attraction of FDI, which at least since the '90s characterised the government approach.

Below the first-tier, the second and third tier manufacturers are usually smaller firms, which are in charge of simpler and lower value-added production. The network of small firms in Thailand is large, and it is made up by about 1700 mainly Thai-capitalised SMEs (BoI, 2015). In general, the local supplier products have a lower quality than those of foreign ones.

Many of these actors have not even been able to satisfy the quality standards required to enter the OEMs supply chain, and therefore became "non-tier", that is they are relegated in the aftermarket (Doner, 2009).

\section{Factors in the Development of Thailand's Automotive Industry}

There is little doubt that the present state of the sector in the country is the result of a long history of interactions between the development project of national public institutions, the actual shape that it took in the form of industrial policies for the automotive sector, the pressures of the several economic actors in the field and the transformations of the international context.

\subsection{International capitals and the role of Japanese companies}

Japanese primacy in the country stems essentially from historical reasons. The Japanese carmakers were in Thailand since the '60s (Doner, 1991), but their presence was intensified particularly from the second half of the ' 80 s and in the beginning of the ' $90 \mathrm{~s}$. Such enlargement of the production base allocated to the country was brought about by the expansion of Japanese capital in Southeast Asia that took place in the '80s, due to several reasons concerning both the sector and the international economic context as a whole. In the middle of the '80s, given the commercial war that exploded between Japan and the U.S., with the Plaza Agreements (1985) the first was forced to appreciate its currency in order to lessen the competitive strength of its products in the U.S. market (Arrighi, 2008). As the value of the yen doubled between 1985 and 1988, the costs of production for Japanese-based firms grew rapidly. The cost pressures and the need to overcome trade restrictions from the U.S. constituted "an irresistible rationale for direct foreign investment" (Hill and Lee, 1994; p. 298), that were directed to the U.S. and to the neighbour countries, first towards the Northeast

\footnotetext{
${ }^{9}$ The sales value of the subsector in 2014 is 844,488 million US dollars, as reported by Statista.com.

${ }^{10}$ Source: Automotive News (2015).

${ }^{11}$ Source: Marklines.com.
} 
Asian, and then towards Southeast Asian ones (see among others Bernard and Ravenhill, 1995; Hart-Landsberg e Bruknett, 1998; Peng, 2000; Felker, 2003). Such process hit massively the car sector, giving birth to a regional production network involving the main ASEAN countries, above all Thailand. The Japanese automakers changed radically their attitude as "reluctant multinationals" (Hill and Lee, 1994) and became main agents of a regional division of labour. In this process of placing themselves at the center of the regional network, they were strongly supported by several regional agreements on integration and by the Japanese public agencies (see Noble, 2001; Kobayashi, Jin and Schroeder, 2015; Staples, 2008; Hill and Lee, 1994 and many more).

In a second phase, the regional production network started to involve not only car assemblers, but also Japanese supply chain. The members of the automotive keiretsu where pushed by the OEMs to move abroad to follow them - the so called follow sourcing mechanism, so that the overseas production could keep the same quality standards as at home and automakers could rely on consolidated buyer-supplier relations (Humphrey and Salerno, 2000; Doner, Noble and Ravenhill, 2004; Hatch, 2005).

The Asian Crisis (1997-1998) boosted the inflow of FDI for the production of vehicles to Thailand, framed as a central location of the regional production network. On the one hand, the economic downturn that followed the speculative attack to the baht - the Thai currency determined a fall in the domestic market for motor vehicles, that reduced by 38.36 percent in 1997 and by 60.44 in 1998 (Techakanont, 2008; Natsuda and Thoburn, 2013). Such collapse caused a drastic drop in production, which plunged to one third of pre-crisis levels (Busser, 2008). On the other hand, the devaluation of the baht, from 1:25 to 1:40 with respect to the U.S. dollar ${ }^{12}$, made Thai exports very competitive on the international markets (Kasuga, Oka, Yamaguchi, Higa and Hoshino, 2005). This determined a huge inflow of FDI: while between 1970 and 1995 the annual average investments to the country was around 26.5 millions of dollars, the figure peaked to 818 million in 1998 (Kohpaiboon, 2008).

As a consequence of both favourable macroeconomic conditions in post-crisis era and - as we shall see in next section - the policies implemented in the '90s, foreign companies, above all Japanese and subsequently U.S., have transformed Thailand in a regional and global export hub (Kobayashi, 2014a; Kohpaiboon, 2009, 2008; Techakanont, 2008, 2012). A further growth in production and exports was also due to the localization of Japanese component makers in the country, which used both the channel of their traditional Japanese buyers in Thailand and that of the industrial groups they were linked to (Busser, 2008).

\subsection{National Policies for the Car Sector in Thailand}

The development and the evolution of the automotive sector in the country were not only due to the transformation of the international environment and to exogenous factors. In fact, an important role has been played by the government activity to promote the automotive industrialization, although with mixed results.

Industrial policy initiatives for the car sector started in the '60s. Such interventions, together with the decision-making processes that generated them, involved many interest groups and lobbies, from Japanese manufacturers to local suppliers, and were also influenced by the unstable political environment and the several coup d'etat the country underwent to (Doner, 1991; Lauridsen, 2004).

The history of industrial policies for the sector in the country can be divided in four periods, characterised by different approaches that inspired the initiatives: 1) import substitution strategies in the '60s, 2) performance requirements and incentives to the entry of

\footnotetext{
${ }^{12}$ Source: authors' elaboration on World Bank data.
} 
foreign capitals between the '70s and the '80s, 3) liberalisation in the '90s and 4) selective strategies in the 2000s.

1) In the '60s, the implemented policies were mainly based on import substitution to promote the development of the assembly stage. In particular, in this period the governments raised the import tariffs on Completely Built Up (CBU) vehicles. The entry barriers were increased for Completely Knocked Down (CKD - whose only assembly stage was implemented in the country) vehicles too, however, their imports resulted more convenient than CBUs (Natsuda and Thoburn, 2014, 2013). Between 1960 and 1962, the Board of Investments (BoI) issued the Industrial Investment Promotion Act, which established total exemptions or tariff reductions for imports of inputs and machinery and for the entry in the country of foreign engineers and technicians.

Next to the attraction of foreign firms to implement assembly stage in the country, the target of such interventions was to promote the collaborations between foreign automakers and national conglomerates, above all through the establishment of joint ventures. While Japanese OEMs, which were already interested in expanding their production bases in the country, complied with the obligation to build up joint ventures, Western manufactures were discouraged by this rule in investing in the still small market of the country (Busser, 2008). Apart from Thai Motor Industry, the first joint venture in the sector born in 1961 whose foreign partner was Ford, the next five foreign firms that entered the sector from 1961 to 1969 were all Japanese (Busser, 2008; Natsuda and Thoburn 2013; Kaosa-adr, 1993).

Although the number of vehicles produced in the country grew (Kaosa-adr, 1993), it seems to us incorrect to maintain that in this first phase the policies generated the take-off of the industry. In fact, during the whole decade the production showed low figures and was exclusively oriented towards the small domestic market. Additionally, the absence of legal entry barriers to the sector caused overcapacity problems, while the dependence on CKD imports generated large deficits in the country trade balance (Natsuda and Thoburn, 2013; Doner, 1991).

2) The inexistence of a general plan for the sector, the presence of an excessive amount of plants and the overcapacity were well-known issues for the national political elites and economic actors. Therefore, at the end of the '60s, an attempt to promote the localisation in the country of further production phases. However, the constant political turmoil that would characterise the next decade, together with the pressures of conflicting economic and social forces, allowed only a partial accomplishment of the growth objective fixed for the sector.

The first plan for the industry, the Automotive Industrial Plan (AIP-1971), was issued in 1971 (Doner, 1991). At the beginning, the plan mainly included three measures: a) fixing local content requirements; b) obligations of a minimum installed production capacity; c) in order to encourage the reach of scale economies, a limit to the number of models each automakers could produce (Kaosa-ard, 1993).

However, the AIP-1971 was never implemented as such. The minimum production capacity and the upper limit to the number of models, that were the main measures aimed at rationalising the sector, were deleted, following the pressures of single local assemblers, once a new army elite took the power after a coup d'etat in 1972 (Kaosa-ard, 1993; Doner, 2009; Natsuda and Thoburn 2013).

The following five years were characterised by great political instability: many governments succeeded one after the other and the particular interests of ministries, military elites, Japanese OEMs and suppliers and Thai components makers prevented the determination of a consistend industrial strategy (Doner, 1991). Some of the problems that affected the sector before were indeed amplified: the policy of local content requirements, in fact, encouraged the attraction of foreign - particularly Japanese - suppliers. However, this 
generated an increase of the already large trade deficit with Japan, as the growth of the sector's overcrowding due to the entry of Western automakers; additionally, the sector continued to suffer from quality issues of products and high average prices (Natsuda and Thoburn, 2013).

At the end of the '70s the political situation stabilised and the local part manufactured associated in a unique lobby group named Thai Auto-Part Manufacturing Association (TAPMA). This gave rise to a new phase of industrial policymaking (Doner 1991, 2009; Hill and Fujita, 2012): in 1978, CBU imports were banned and the import tariffs for CKDs were raised. Later, also the local content requirements were increased hugely. Additionally, a Mandatory Deletion Programme (MDP) was instituted ${ }^{13}$. Such set of policy initiatives considerably reduced the number of small players in the market, leaving the larger Japanese automakers and their supply chain to lead the production (Kaosa-adr, 1993).

In the middle of ' $80 \mathrm{~s}$, the policies continued to target the attraction of foreign direct investments. This time, however, the purpose was less generalist and more focused on specific types of products and phases of production: in 1986 a new programme of incentives encouraged the production in the country of diesel engines (Doner, 1991; Natsuda and Thoburn 2014). Initially, the BoI established that only one manufacturer could join the programme, in order to avoid excessive capacity in an infant production niche. However, the actors in the playing field mitigated the initial projects of the governments: in the end, three Japanese automakers were included, and they participated jointly in the project to exploit a common supply base and reach economies of scale together (Doner, 1991; Techakanont, 2008).

In the same decade, the public authorities developed also some initiatives for colocalisations of productions in specific industrial areas around Bangkok, in the districts of Samut Prakan, Bang Chan and Lad Krabang (Natsuda and Thoburn, 2013). In this case, the purpose of the government was to transform this region in a pole of attraction for foreign firms, through specific fiscal and non-fiscal incentives. As a result, Toyota, Nissan, Isuzu, Hino, Mitsubishi and Mazda, followed by their Japanese suppliers, placed their plants in the area in the following years (Techakanont, 2008).

3) In 1991 the automotive sector in Thailand suffered from high levels of saturation: there were 11 automakers that produced 16 brands for a total of 42 models. This was happening in a country whose annual domestic sales amounted only to 304.000 units (Doner, 2009).

Between 1991 and 1994, the new government, that rose in power after the umpteenth military coup d'etat, implemented liberalisation measures regarding taxes, import tariffs, export incentives and property regimes, aimed at mitigating the sector inefficiency. The upper limit of less than 50 percent of ownership by foreign actors was abolished (Noble, 2001), under the condition that the firms born under the new regime earned more than 60 percent of their revenue from exports (Kaosa-adr, 1993). Additionally, the restrictions on the number of models and the ban on CBU were deleted (Kohpaiboon, 2008; Doner, 2009).

Another set of measures intervened with the aim of strengthening the local supply chain. This work stream was carried out simultaneously by two government agencies - the BoI and the Ministry of Industry: the first instituted the BoI Unit for Industrial Linkages Development (BUILD), with the purpose of promoting the supporting industry and assisting Thai SMEs in developing linkages with foreign manufacturers. The Ministry of Industry, in collaboration with Japanese national agency, developed a plan to support the auto parts and the electronic sectors (National Supplier Development Program - 1994, Master Plan for Supporting Industries - 1996). Overall, the efficacy of such measures was criticised by

\footnotetext{
${ }^{13}$ This was a list of components that the CKD importers were forced to delete from the kit in order to import it in the country, and its main purpose was in practice to stimulate the production of such parts in the country.
} 
several literature contributions (among others Doner, 2009; Lauridsen, 2004), as they were fuelled by very limited - or absent - financial resources and were based upon the premise that foreign firms should become the key actors in the development of national production network.

With the fall of the financial sector during the Asian Crisis (1997-1998), several local firms went bankrupt or were took over by their foreign partners, generating what has been defined as the denationalisation of the sector (Doner, 2009). Additionally, in the following years the abolition of the local content requirements was announced, and it was realized in 2000 in compliance with the WTO-entry requirements. In the aftermath of the crisis, however, some studies underlined that such measures had not provided a solution to the most serious issues of the national sector - and of the national production system as a whole - that is the limited R\&D activity and, more generally, the low level of development of industrial technologies (Laurdisen, 2009).

4) Thai governments in 2000s - particularly those leaded by Thaksin, 2001-2006 intervened with a development strategy for the sector focused on specific market niches what Natsuda and Thoburn $(2013,2014)$ defined as picking the winning model strategy. This consisted in the establishment of fiscal benefits for the production in the country of specific types of final vehicles. The first product addressed in 2000-2002 was the 1-ton pick-up trucks, and the related set of measures seemed to be successful: in the following years, both Toyota and Isuzu moved the entire production of light pick-up to Thailand, followed by Mazda and Ford that made the country their export hub for these vehicles (Natsuda and Thoburn 2013; Kohpaiboon, 2008). Consequently, the production of light commercial vehicles has grown steeply since 2000 on (fig. 5). However, several authors stress again that this was not followed by a comparable growth in technological capacities of local manufacturers, and that the development of the product is mainly left to foreign actors (Doner, 2009; Lauridsen, 2009).

A further policy initiative for the sector, that was central in the decade and still continues nowadays, is that of clustering: starting from 2001, the automotive was identified as one of the 5 sectors for which to promote the localisation in specific geographical areas of the country. In particular, it was intended to move the production from the crowded industrial areas around Bangkok towards the district of the Eastern Seabord in the provinces of Rayong, Chaochengsao e Chonburi. Such intervention, for which the government asked for the involvement of the economist and policy consultant Michael Porter, was considered to be crucial mainly given the sector's condition in the country, that suffered from low wages, low productivity and the focus on the limited niche of light pick-up trucks (Porter, 2003; Lauridsen, 2009).

Fig. 5 - Total and pick-up production 


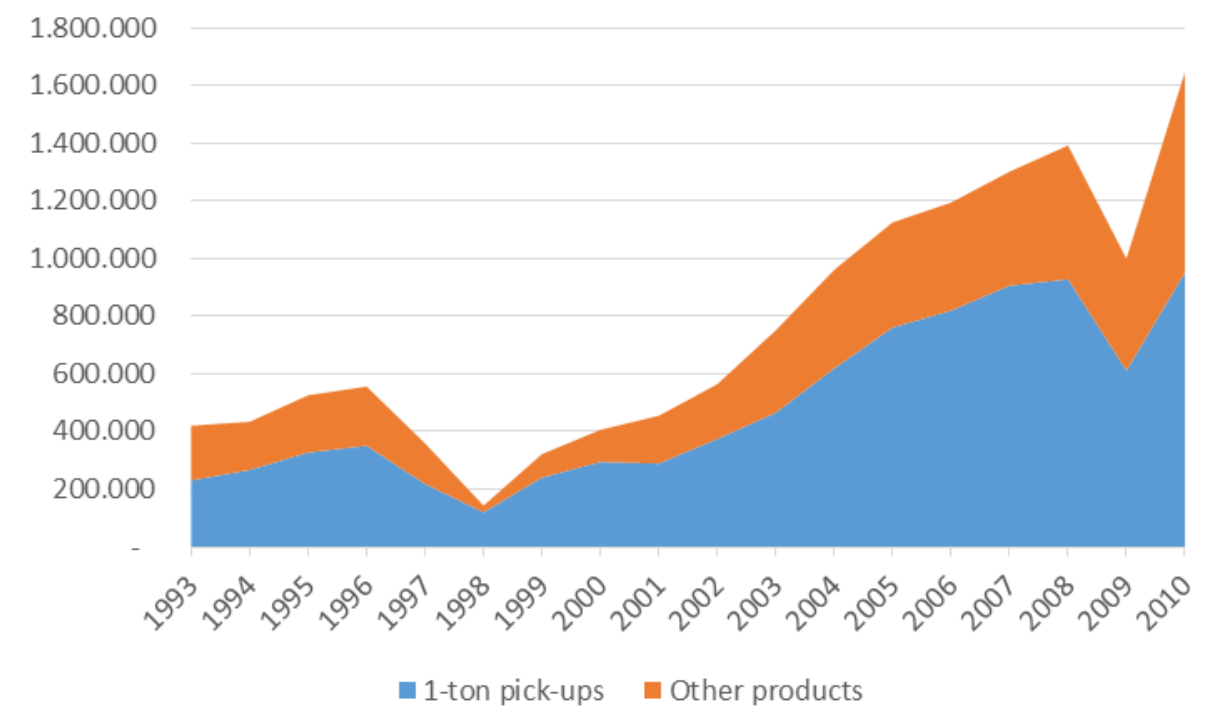

Source: authors' elaborations on Thailand Auto Industry Association data.

After the experience of pick-ups, the picking the winning model strategy was replicated in the Master Plan 2007-2011 with the Eco-cars (small energy-efficient passenger vehicles), seen as an important alternative to the light-commercial vehicle niche and as a way to satisfy the increasing demand for passenger vehicles by the growing Thai middle class (Natsuda e Thoburn, 2013 e 2014; Doner, 2009). Besides the incentives for the production of Eco-cars, in the Master Plan the government established also objectives regarding the strengthening of local competencies and of the domestic supply chain. The Ministry of Industry and the BoI's intentions were multiple. First, they aimed at increasing the technological capability and the quality of the production of the second tier of the supply chain. Additionally, a project for the institution of the Centre of Excellence for the development of engineering and design competences was launched. The Plan also aspired to enhance the training of the human capital involved in the production process. However, as explained by the promoters themselves (Thailand Automotive Institute and Ministry of Industry, 2012), the Plan had a very limited success. The realised initiatives were carried out discontinuously; the training activity was entrusted almost totally to the automakers, which indeed only trained the production employees and not the R\&D staff; finally, regarding the measures for the development of engineering competencies, the public authorities limited their effort to the issuing of fiscal benefits.

The problems related to the lack of competencies of the production milieu and to the insufficient training of human capital, highlighted since the Asian crisis, continue to be main points in the agenda of policies on automotive in the country, as it is clear from the last available Auto Master Plan (2012-2016). The long-term declared aim of such plan is to transform Thailand into a global production base for green automotive, while developing a strong domestic production network. In particular, the plan refers to the establishment of three Centres of Excellence and two "good business environments" that should be focused on: a) the development of R\&D for green technology and high-level technology components; b) the development of human capital through dedicated infrastructures and public-private partnerships; c) the strengthening of the supply chain (Thailand Automotive Institute and Ministry of Industry, 2012). However, the plan does not specify the modes of organisation, the nature, the structure and the subjects involved in this projects.

The analysis of Thai policies for automotive indicates that, differently from the experience of other East Asian Countries (such as South Korea, China, Malaysia, Vietnam), Thai governments never prioritised the support to national champions to develop the sector, 
privileging on the other hand the attraction of foreign direct investments. If this allowed the country to become a central hub in vehicles manufacturing and export, it has nevertheless determined a substantial weakness of local production base and a strong dependency on Japanese technological resources. For this reason, it does not seem correct to describe Thailand as a true success case, as the policies implemented so far do not seem to have answered in a satisfactory way to the needs of the national productive structure.

\section{Concluding Remarks}

The analysis of the automotive sector in Thailand gives a useful opportunity to make some considerations on the effects of selective industrial policies. We may interpret the policies dedicated to the automotive in Thailand from two different perspectives. On the one hand, we may look at the results of the policy in terms of the evolution of the sector over time (in terms of production capacity, exports, international position and so on). In this case, it is very difficult to maintain that the interventions in support to vehicles production - although coupled with exogenous factors - did not substantially contribute to strengthen the role of the country in the global production chain.

According to a second perspective, however, we may consider what results the selective policy had in terms of effective local capabilities development, with respect to the of value added created and captured by the territories, the technology and knowledge actually transferred to the local actors etcetera. In other words, by using this approach we may want to understand how much the sector prosperity translates into the local communities' well-being. For this to happen, it is in our opinion essential that the development of the sector includes the participation and growth of national actors. As an example, we may think about the experience of selective policies in China during its gradual process of opening to market economy (Barbieri, Di Tommaso and Rubini, 2009a). The initial policy of foreign firms attraction in carefully controlled and clearly bounded areas (Di Tommaso and Rubini, 2005) has contributed substantially to the expansion of manufacturing. However, in the following years this approach has also developed a propensity towards the fulfilment of local development objectives. In fact, on the one hand Chinese governments have demonstrated large autonomy in the definition of industrialisation purposes in the short, middle and long term, and, on the other, they were able to pursue them by balancing the presence of foreign actors and the developmental aims towards local firms (Barbieri, Di Tommaso and Rubini, 2009b), also with specific reference to the automotive sector (Pollio et al., 2016). However, even a success case like this shows several problems related to the long-run sustainability of the process of economic development, to the non-inclusive nature of the decision-making process and to the potential risks of government failures related to the transparency of choices and to lobbies power (Barbieri, Di Tommaso and Tassinari, 2015).

Based on such considerations and on the analysis we made in this paper, some distinctive elements of Thailand's automotive sector policies experience emerge. As we showed, Thailand nowadays hosts the largest OEMs and suppliers in the world. These actors develop in the country designing, production and final assembly stages. The sector is among the main ones in terms of contribution to the national GDP and exports, and even if we did not provide an empirical verification, it is most likely that the current state of the sector is linked to the policies implemented since the '60s, here included the strategy of picking the winning model. Therefore, it seems to us that these policies may have encouraged the expansion of the sector per se, that is the first perspective that we identified to analyse the results of selective policies. On the other hand, the effects in terms of local development of these initiatives seem more limited. In many of the official documents supporting the sector development, Thai authorities have often underlined the importance of strengthening the technological endowment of the local production base. However, such interventions were 
seldom fully implemented, given the pressures by powerful economic or social lobbies towards usually weak and unstable governments. This lead to a case where the expansion of the sector is continuously enhanced - also because it is linked to such power groups requests - without a parallel development of the national production environment.

In our opinion, the true challenge for the future sustainability of the automotive sector in this country is to find a way to overcome these weaknesses, which are clearly linked to government failures cases (Di Tommaso and Schweitzer 2013; Tassinari, Di Tommaso, Bonnini and Marozzi, 2014). In particular, it may be beneficial for the sector's future trends to implement policies that are able to ground on the strong presence of global important actors in the sector in order to transfer technology and competences to the local base, so that these may gradually acquire autonomous and improved innovation capabilities.

\section{References}

Angelino, A., and Masina, P.P. (2014), "L'industria malese nella trappola del medio reddito", L'industria, Vol. 35 N.3, pp. 549-562. (in Italian).

Arrighi, G. (2008). Adam Smith a Pechino: genealogie del ventunesimo secolo, Feltrinelli, Milano (in Italian).

Barbieri E., Di Tommaso, M.R., and Rubini, L. (2009a), "Industrial development policies in Southern China: the specialised towns programme", Economia e Politica Industriale, Vol. 3, pp. 179-198.

Barbieri E., Di Tommaso, M.R., and Rubini, L. (2009b), Industria Contemporanea: Governi. Imprese e Territori nella Cina Meridionale, Carocci, Roma (in Italian).

Barbieri, E., Di Tommaso, M.R., and Tassinari, M. (2015), "Politiche industriali selettive e settori strategici. Lo scenario e le scelte di Pechino", L'industria, Vol.36 N.3, pp. $403-$ 434 (in Italian).

Bernard, M., and Ravenhill, J. (1995), "Beyond Product Cycles and Flying Geese. Regionalization, Hierarchy, and the Industrialization of East Asia", World Politics, Vol.47 N.2, pp. 171-209.

Board of Investments (BoI) (Eds.) (2015), "Thailand: Global Green Automotive Production Base", available at: http://www.boi.go.th/upload/content/BOI-brochure\%202015automotive-20150325_70298.pdf (accessed 1 November 2017)

Busser, R. (2008), "'Detroit of the East'? Industrial Upgrading, Japanese Car Producers and the Development of the Automotive Industry in Thailand", Asia Pacific Business Review, Vol.14 N.1, pp. 9-45.

Di Tommaso, M.R., and Angelino, A. (2015), "Hanoi tra Washington e Pechino. La crescita industriale vietnamita tra export-led growth e pianificazione selettiva", L'industria, Vol.36 N.3, pp. 351-380 (in Italian).

Di Tommaso, M.R. and Rubini, L. (2005) "La geografia della produzione nel Guangdong: agglomerazioni di imprese e città specializzate", in: Bellandi M. and Biggeri M. (Eds.), La sfida industriale cinese vista dalla Toscana distrettuale, Stibu, Urbania (in Italian).

Di Tommaso, M.R. and Schweitzer, S.O. (2013) Industrial Policy in America: Breaking the Taboo, Edward Elgar Publishing, Cheltenham.

Di Tommaso, M.R., Rubini, L. and Barbieri, E. (2013), Southern China. Industry, Development and Industrial Policy, Routledge, London and New York.

Doner, R.F. (1991), Driving a Bargain - Automobile Industrialization and Japanese Firms in Southeast Asia, University of California Press, Berkeley and Los Angeles.

Doner, R.F. (2009), The Politics of Uneven Development, Cambridge University Press, Cambridge, UK.

Doner, R.F., Noble, G.W. and Ravenhill, J. (2004), "Production Networks in East Asia's Auto Parts Industry", in: Yusuf, S., Altaf, M. A. and Nabeshima, K. (Eds.), Global 
Production Networking and Technological Change in East Asia, The World Bank, Washington DC.

Felker, G.B. (2003), "Southeast Asian industrialisation and the changing global production system", Third World Quarterly, Vol.24 N.2, pp. 255-282.

Frigant, V. (2011) "Egyptian Pyramid or Aztec Pyramid: How Should We Describe the Industrial Architecture of Automotive Supply Chains in Europe?" Cahiers Du GREThA $N^{\circ}$ 2011-27.

Hart-Landsberg, M. and Burkett, P. (1995), "Contradictions of Capitalist Industrialization in East Asia: A Critique of 'Flying Geese' Theories of Development", Economic Geography, Vol.74 N.2, pp. 87-110.

Hatch, W.F. (2005), "Transplanting Keiretsu", The Japanese Economy, Vol.33 N.2, pp. 5466.

Hill, R.C. and Lee, Y.J. (1994), "Japanese Multinationals and East Asian Development - The case of the automobile industry", in: Sklair L. (Ed.) Capitalism, \& Development, Routledge, London.

Hill R.C. and Fujita K. (2012), "'Detroit of the East': A Multiscalar Case of Regional Development Policy in Thailand", in: Park B-G, Hill R.C., and Saito A. (Eds.), Locating Neoliberalism in East Asia: Neoliberalizing Spaces in Developmental States, Wiley Blackwell, Chichester.

Humphrey, J. and Memedovic, O. (2003), "The Global Automotive Industry Value Chain: What Prospects for Upgrading by Developing Countries", UNIDO Sectoral Studies Series, Vienna.

Humphrey, J. and Salerno, M.S. (2000), "Globalisation and Assembler-Supplier Relations: Brazil and India", in: Humphrey, J., Lecler, Y., and Salerno, M. (Eds.) Global Strategies and Local Realities, Macmillan Press, Basingstoke and London.

Intarakumnerd P. and Charoenporn P. (2015), "Impact of stronger patent regimes on technology transfer: The case study of Thai automotive industry", Research Policy, Vol.44 N.7, pp.1314-1326.

Johri, L.M. and Petison, P. (2008), "Value-based localization strategies of automobile subsidiaries in Thailand", International Journal of Emerging Markets, Vol.3 N.2, pp. $140-162$.

Jomo, K.S. (2005), "Developmental States in the face of globalization: Southeast Asia in comparative East Asian perspective", Centre for African Studies Seminar Series, (October), pp. 1-17.

Kaiser, U. (Ed.) (2014). Thailand AutoBook 2015, BDA Business Development Thailand, available at: http://www.thaiautobook.com.

Kaosa-ard, M.S. (1993), "TNC Involvement in the Thai Auto Industry", TDRI Quarterly Review, Vol.8 N.1, pp. 9-16.

Kasuga T., Oka, T., Yamaguchi Y., Higa Y. and Hoshino, K. (2005), "The Expansion of Western Auto Parts Manufacturers into Thailand and Responses by Japanese Auto Parts Manufacturers", JBICI Review, Vol.11, pp. 1-35.

Kobayashi, H. (2014a), "Current State and Issues of the Automobile and Auto Parts Industries in ASEAN", In: Research Institute Auto Parts Industry, Waseda University (eds.) Automobile and Auto Components Industries in ASEAN: Current State and Issues.

Kobayashi, H. (2014b), "Preface", In: Research Institute Auto Parts Industry, Waseda University (eds.) Automobile and Auto Components Industries in ASEAN: Current State and Issues.

Kobayashi, H. Jin, Y., and Schroeder, M. (2015), "ASEAN economic community and the regional automotive industry: impact of ASEAN economic integration on two types of 
automotive production in Southeast Asia", International Journal of Automotive Technology and Management, Vol.15 N.3, pp.268 - 291.

Kohpaiboon, A. (2008), "Thai Automotive Industry: Multinational Enterprises and Global Integration", Economic Research and Training Center, Thammasat University, Discussion Paper Series, (4).

Kohpaiboon, A. (2009), "Global Integration of Thai Automotive Industry", Thammasat University, Discussion Paper Series, (16).

Lall, S. (2004), "Selective Industrial and Trade Policies in Developing Countries: Theoretical and Empirical Issues", in: Soludo, C., Ogbu, O. and Chang, H.-J. (Eds.) The Politics of Trade and Industrial Policy in Africa. Forced consensus?, Africa World Press, Trenton and Asmara.

Lauridsen, L.S. (2004), "Foreign Direct Investment, Linkage Formation and Supplier Development in Thailand during the 1990s: The Role of State Governance", European Journal of Development Research, Vol.16 N.3, pp. 561-586.

Lauridsen, L.S. (2009), "The Policies and Politics of Industrial Upgrading in Thailand during the Thaksin Era (2001-2006)", Asian Politics and Policy, Vol.1 N.3, pp.409-434.

Natsuda, K., and Thoburn, J. (2013), "Industrial policy and the development of the automotive industry in Thailand", Journal of the Asia Pacific Economy, Vol.18 N.3, pp. 413-437.

Natsuda, K. and Thoburn, J. (2014), "How much policy space still exists under the WTO? A comparative study of the automotive industry in Thailand and Malaysia", Review of International Political Economy, Vol.21 N.6, pp. 1-32.

Noble, G.W. (2001), "Congestion Ahead: Japanese Automakers in Southeast Asia", Business Politics, Vol.3 N.2, pp. 157-184.

Office of Industrial Economics Ministry of Industry (Eds.) (2006), "Automotive Industry in Thailand", available at http://www.oie.go.th/industrystatus2/En_AutomotiveIndustryinThailandJune2006.pdf

Ohno, K. (2009), "Avoiding the Middle-Income Trap, Renovating Industrial Policy Formulation in Vietnam", ASEAN Economic Bulletin, Vol.26 N.1, pp. 25-43.

Peng, D. (2000), "The changing nature of East Asia as an economic region", Pacific Affairs, Vol.73 N.2, pp. 171-191.

Phongpetra, V. and Johri, L.M. (2011), "Impact of business strategies of automobile manufacturers in Thailand", International Journal of Emerging Markets, Vol.6 N.1, pp. 17-37.

Pianta, M. (2014),"An Industrial Policy for Europe", Seoul Journal of Economics, Vol.27 N.3, pp. 277-305

Pollio, C., Barbieri, E., Rubini, L. and Di Tommaso, M.R. (2016), "Attrarre basta per innovare? La via cinese nell'industria dell'auto", L'industria, Vol.37 N.4, pp. 537-564 (in Italian).

Porter, M.E. (2003), "Thailand's Competitiveness: Creating the Foundations for Higher Productivity", Institute for Strategy and Competitiveness, Bangkok, 4 May.

Staples, A. (2008), Responses to Regionalism: Corporate Strategy in East Asia, Palgrave Macmillan, London.

Sturgeon, T.J., Memedovic, O. and Van Biesebroeck, J. (2009), "Globalisation of the Automotive Industry: Main Features and Trends", International Journal of Technology Learning, Innovation and Development, Vol.2 N.1/2, pp. 7-24.

Sturgeon, T.J., Van Biesebroeck, J. and Gereffi, G. (2008), "Value Chains, Networks and Clusters: Reframing the Global Automotive Industry", Journal of Economic Geography, Vol.8 N.3, pp.297-321. 
Tassinari M., Di Tommaso M.R., Bonnini S. and Marozzi M. (2014), "La Terza Italia di fronte alla Crisi e alla crescita delle nuove potenze manifatturiere. Una metodologia di supporto alle decisioni di politica industriale regionale", Economia Marche. Journal of Applied Economics, Vol.33 N.2, pp. $43-67$ (in Italian).

Techakanont K. (2008), "The Evolution of Automotive Clusters and Global Production Network in Thailand", Faculty of Economics of Thammasat University Discussion Papers Series, (6).

Techakanont, K. (2012), "New Division of Labor between Thailand and CLMV Countries: The case of Automotive Parts Industry", in: Ueki, Y. and Bhongmakapat, T. (eds.) Industrial Readjustment in the Mekong River Basin Countries: Toward the AEC. BRC Research Report (7). Bangkok: Bangkok Research Center, IDE-JETRO.

Thailand Automotive Institute and Ministry of Industry (2012), Master Plan for Automotive Industry 2012-2016, Report, December.

World Bank (1993), The East Asian Miracle, Oxford University Press, New York.

Worwick, K. and Nolan, A. (2014), "Evaluation of Industrial Policy: Methodological Issues and Policy Lessons", OECD Science, Technology and Industry Policy Papers, 16. 